\title{
Extensive rearing hinders Maedi-Visna Virus (MVV) infection in sheep
}

\author{
Iratxe LEGINAGOIKOA ${ }^{\mathrm{a}}$, Ramón A. JUSTE ${ }^{\mathrm{a}}$, Jesse BARANDIKA ${ }^{\mathrm{a}}$, \\ Beatriz AMORENA ${ }^{\mathrm{b}}$, Damián DE ANDRÉS ${ }^{\mathrm{b}}$, Luis LUJÁN ${ }^{\mathrm{c}}$, Juan BADIOLA ${ }^{\mathrm{c}}$, \\ Eduardo BERRIATUA ${ }^{\mathrm{a}, \mathrm{d} *}$
}

\author{
${ }^{a}$ Instituto Vasco de Investigación y Desarrollo Agrario-NEIKER, Derio, Bizkaia, Spain \\ ${ }^{b}$ Instituto de Agrobiotecnología y Recursos Naturales, CSIC-UPNA, Pamplona, Spain \\ c Patología Animal, Universidad de Zaragoza, Zaragoza, Spain \\ ${ }^{d}$ Enfermedades Parasitarias, Facultad de Veterinaria, Universidad de Murcia, 30100 Campus de \\ Espinardo, Murcia, Spain
}

(Received 10 October 2005; accepted 3 May 2006)

\begin{abstract}
Maedi-Visna Virus (MVV) seroprevalence and its relationship with housing and mode of rearing of replacement ewe-lambs was investigated in 38 non-randomly selected sheep-flocks in Spain. They included extensive lamb-producing Manchega cross-bred flocks raised almost permanently at pasture, semi-intensive Latxa dairy flocks housed 2-8 months/year and intensively raised Assaf dairy flocks housed most time and at higher stocking density in less ventilated buildings than other flocks. Most flocks raised replacement lambs naturally with their dams until weaning and as a separate flock thereafter until lambing at one year of age. Seroprevalence $(95 \%$ confidence intervals) was 77\%, 25\% and 5\% (4-6) in intensive, semi-intensive and extensive flocks, respectively and the median (interquartile range) flock-seroprevalence was 82\% (66-94) in intensive flocks, 31\% (14-31) in semi-intensive flocks and 4\% (0-7) in extensive flocks. Seroprevalence was lowest in one year-old sheep and increased to flock levels during the year after introduction into the adult flock in most intensive flocks and more gradually in other flocks. Adult flock seroprevalence was associated with housing time but this relationship was not evident within a particular rearing system, indicating that other unknown factors are critical in horizontal MVV-transmission. Low seroprevalence in extensive flocks further supports previous indications that lactogenic MVV-infection is relatively inefficient and horizontal transmission is necessary to ensure long-term maintenance of MVV and this could explain that MVV has not been reported from countries with mainly extensively reared sheep such as Australia and New Zealand. Moreover, it indicates that MVV-control in extensive and semi-intensive flocks can be simple and inexpensive.
\end{abstract}

Maedi-Visna Virus / sheep / seroprevalence / intensive and extensive rearing / Spain

\section{INTRODUCTION}

Maedi-Visna Virus (MVV) and the closely related Caprine Arthritis Encephalitis virus (CAEV) are grouped as Small Ruminant Lentiviruses (SRLV) be-

\footnotetext{
*Corresponding author: berriatu@um.es
}

longing to the retroviridae family. Both can infect sheep and goats causing a slow, degenerative and fatal disease of the lungs, central nervous system, mammary gland and joints that can result in very significant production losses and have major welfare implications (recently reviewed by 
$[21,24])$. Viral tissue tropism depends on the infecting strain and on the host's genetics. Disease is often not apparent until two years or more after initial infection, which occurs from ingesting colostrum and milk from infected dams and from horizontal contact with lung secretions and excretions from infected sheep. There is evidence that transplacental infection may occur, however this route of infection is considered of limited epidemiological importance and there is now ample epidemiological and experimental evidence indicating that horizontal infection is the main form of SRLV-infection in animals raised with some degree of confinement [7]. For example, in semi-intensively reared Latxa dairy sheep flocks housed for 26 months/year the efficiency of horizontal infection is such that lactogenic transmission does not significantly increase the risk of MVV-seroconversion [6]. Moreover, there is some recent evidence that SRLV-infection is low or even absent in extensively reared sheep flocks and goat herds in Patagonia $[25,26]$. The risk of lactogenic SRLV-infection has only been partially quantified and the percentage of naturally raised lambs that become infected from suckling colostrum from seropositive dams has been estimated at approximately only $20 \%[2,3]$. If the risk of lactogenic infection during the preweaning period is below $1(100 \%)$ then it is evident that some other form of infection is necessary to achieve an $\mathrm{R}_{\mathrm{e}}$ (effective reproduction ratio: average number of secondary infections produced by one infected individual) value above one, necessary for infection to last in the population [4]. It is possible that in some extensive sheep production systems, sheep do not have sufficiently close contact for horizontal infection to occur, but this has not been investigated. Moreover, little is known of the type and extent of contact between infected and uninfected animals necessary for MVV-infection to occur. Uninfected sheep introduced in an infected flock may quickly become infected, but in some cases uninfected sheep can be housed with other infected sheep for several years without becoming infected and the reasons for this are unknown [17].

The limited knowledge on the mechanisms of MVV-transmission between sheep contrasts with the numerous seroprevalence studies of Maedi-Visna worldwide [14, 24], indicating that MVV has been reported from most major sheep producing countries except Australia and New Zealand [12]. Several studies have shown some evidence of breed associated susceptibility or resistance to MVV-infection and disease [8, 9, 13, 23, 31]. However, very few have attempted to investigate the relationship between infection and sheep management and transmission and control implications. In a previous study by Berriatua et al. [6], incidence of infection in semi-intensive Latxa dairy flocks was relatively low and in most flocks the number of sheep that seroconverted was lower than the number of sheep culled with flock culling percentages being 14-25\% . This offers the possibility of gradually reducing flock seroprevalence by selective culling without increasing the flock's culling percentage and this represents an alternative to the more drastic traditional MVV-control methods based on flock testing and culling of all seropositive animals and their young progeny (or on developing a separate MVV-free flock) [14] and highlights the need for similar investigations in other sheep production systems. In order to investigate this, long-term longitudinal studies have been initiated in extensive and intensive sheep production systems in several regions in Spain. This article reports MVV-seroprevalence, its relationship with housing and mode of rearing preweaned replacement lambs and investigates MVV in control lamb-producing extensive flocks and intensive and semiintensive dairy flocks from southern, central and northern Spain, respectively. 


\section{MATERIALS AND METHODS}

\subsection{Study design and population}

Thirty-eight flocks were investigated including 10 intensive Assaf dairy flocks in Castile-León, 5 semi-intensive Latxa dairy flocks in the Basque Country and 23 extensive lamb-producing Manchega cross Merino or Talaverana flocks in CastileLa Mancha. Resources were not available to investigate more flocks. Moreover, it was initially predicted that approximately 30 flocks of 300 sheep with a similar number of flocks from each production system could be investigated. However, different numbers of flocks from each system were selected because average flock sizes varied between systems, there was no data on seroprevalence of MVV-infection in the extensive Manchega cross-bred flocks and it was necessary to accommodate the study design to detect MVV in this system. Furthermore, given the good knowledge of the epidemiology of MVV-infection in semiintensive Latxa flocks available [2,3,6,17], it was decided to allocate more resources to investigating MVV in other sheep production systems.

The Basque Country is situated in the Atlantic northern region of Spain where the climate is mild and rain ensures green pastures throughout the year. In contrast, Castile represents the Spanish Central Plain situated at around $700 \mathrm{~m}$ above sea level, being dominated by a dry continental climate. Castile-León is the northern part of the Plain and Castile-La Mancha is the southern part of the Plain. In 2004, there were 22.7 million sheep in Spain including $15 \%$ dairy sheep. Castile-León had 4.3 million sheep and produced $60 \%$ of the sheep milk commercialised in Spain and Assaf dairy sheep were present in $86 \%$ of the dairy flocks in the region. Latxa sheep represent $90 \%$ of the 0.4 million ovines in the Basque Country. Manchega cross Talaverana and Merino sheep reared ex- tensively for lamb production like in this study, represent a minority of the 3.2 million sheep in Castile-La Mancha. However, most of the 7.8 million sheep in the neighbouring regions of Extremadura and Andalucía, represented by the Merino breed reared for fine wool production in the past and for lamb production nowadays, are raised similarly and more extensively $[10,18,27]$.

Typical intensive Assaf dairy flocks in Castile-León are made of 200-1000 sheep, the animals are reared almost permanently indoors, their oestrous is not markedly seasonal and they are bred for three lambings in two years. They have a milking period of 7-9 months/year and the average milk production is $400 \mathrm{~kg}$ of milk per ewe (kme). In contrast, Latxa dairy sheep flocks are mostly $<500$ sheep, they lamb once a year in the winter, have a five month milking period with an average milk production of $135 \mathrm{kme}$, and are mostly raised on pasture and housed mostly during lactation at night and in rainy weather. Manchega cross-bred sheep are managed in large size flocks sometimes including several thousand sheep, they are raised extensively in low yielding "dehesa" pastures, and they are not seasonally polyoestrus and cycle all year round. In all three systems, most lambs are weaned at 4-6 weeks of age and sold for slaughter or in Castile, also for fattening in feedlots. The exceptions are replacement lambs that remain with the dam for 2-3 months and that are thereafter kept as a separate flock until after their first lambing at 12-14 month-old, when they join the adult flock.

\subsection{Selection of flocks and animals}

The ten intensive Assaf dairy flocks were selected from a list of 30 flocks under the care of a veterinary practitioner concerned with the high incidence of clinical Maedi-Visna (MV) including animals 
Table I. Flock origin, number, size, breed, production system, median weaning age of replacement lambs and housing time and space in an MVV seroprevalence study in sheep in Spain in 2003-2004.

\begin{tabular}{|c|c|c|c|c|c|c|c|}
\hline \multirow{2}{*}{$\begin{array}{l}\text { Region } \\
\text { Number of } \\
\text { flocks and } \\
\text { flock size }\end{array}$} & \multirow{2}{*}{$\begin{array}{l}\text { Breed } \\
\text { Production } \\
\text { system }\end{array}$} & \multirow{2}{*}{$\begin{array}{c}\text { Median } \\
\text { (range) } \\
\text { weaning } \\
\text { age (days) }\end{array}$} & \multicolumn{5}{|c|}{$\begin{array}{c}\text { Flock median (range) housing time (days) and area }\left(\mathrm{m}^{2}\right) \text { and volume }\left(\mathrm{m}^{3}\right) \text { of } \\
\text { housing available for ewes and replacement lambs }\end{array}$} \\
\hline & & & $\begin{array}{l}\text { Adults } \\
\text { Lambs }\end{array}$ & $\begin{array}{c}\text { Housing } \\
\text { time }^{c}\end{array}$ & $\begin{array}{c}\text { Floor } \\
\text { area/sheep }\end{array}$ & $\begin{array}{c}\text { Shed } \\
\text { volume/sheep }\end{array}$ & $\begin{array}{l}\text { Shed open } \\
\text { area/sheep }\end{array}$ \\
\hline Castile-León & Assaf & $42^{\mathrm{a}}$ & A & 338 & 1.0 & 7.1 & 0.08 \\
\hline $\begin{array}{c}10 \\
211-700\end{array}$ & $\begin{array}{l}\text { Intensive } \\
\text { dairy }\end{array}$ & $(20-60)$ & $\mathrm{L}$ & $\begin{array}{c}(326-365) \\
365 \\
(290-365)\end{array}$ & $\begin{array}{c}(0.6-1.4) \\
1.1 \\
(0.6-2.2)\end{array}$ & $\begin{array}{l}(3.0-17) \\
5.8 \\
(2.6-50)\end{array}$ & $\begin{array}{c}(0.03-0.14) \\
0.26 \\
(0.02-0.75)\end{array}$ \\
\hline Basque & Latxa & $37^{\mathrm{a}}$ & A & 171 & 1.1 & 10.3 & 0.14 \\
\hline Country & Semi- & $(30-43)$ & & $(83-242)$ & $(0.6-2.0)$ & $(3.3-17)$ & $(0.05-0.32)$ \\
\hline $\begin{array}{c}5 \\
272-283\end{array}$ & $\begin{array}{l}\text { intensive } \\
\text { dairy }\end{array}$ & & $\mathrm{L}$ & $\begin{array}{c}242 \\
(123-365)\end{array}$ & $\begin{array}{c}1.0 \\
(0.7-1.6)\end{array}$ & $\begin{array}{c}5.9 \\
(1.7-44)\end{array}$ & $\begin{array}{c}0.26 \\
(0.02-0.86)\end{array}$ \\
\hline $\begin{array}{c}\text { Castile-La } \\
\text { Mancha } \\
23 \\
150-392\end{array}$ & $\begin{array}{l}\text { Cross-bred } \\
\text { lamb } \\
\text { production }\end{array}$ & $\begin{array}{c}62 \\
(45-90)\end{array}$ & A & $\begin{array}{c}10 \\
(1-53) \\
49 \\
(2-153)\end{array}$ & $\begin{array}{c}1.9 \\
(0.4-5.4) \\
1.5 \\
(0.3-4.7)\end{array}$ & $\begin{array}{c}7.9 \\
(0.8-29) \\
5.1 \\
(0.6-22)\end{array}$ & $\begin{array}{c}0.20 \\
(0.07-0.87) \\
0.23 \\
(0.04-1.98)\end{array}$ \\
\hline
\end{tabular}

${ }^{a}$ Excluding flocks that raised lambs artificially preweaning.

${ }^{\mathrm{b}}$ Cross-bred Manchega- Merino and Manchega-Talaverana.

${ }^{c}$ Calculations exclude seven extensive flocks where sheep were not housed.

with a typical yet comparatively uncommon, Visna nervous form [5]. They were the only ones in the list registered with the local Milk-Board. Sheep were born and bred at home, uniquely identified and had dates of birth accurate to the month and year for three years prior to the start of this study. The five selected semi-intensive Latxa dairy flocks had participated in previous MVV serological and control studies continuously since the early 1990s, they had no reported MV clinical cases for almost a decade and the farmers were keen to continue testing for MVV-infection. They were considered among the most professionalised and intensively raised flocks in the region and except one flock, none had incorporated outside sheep for several years preceding the study. Sheep were uniquely identified and had precise dates of birth. The 23 Manchega cross-bred flocks selected for the study were from clients of a veterinarian that had expressed interest in investigating MVV although he had never diagnosed a case of MVV-infection. To maximise resources, selected flocks included all the flocks under his care with $<500$ sheep. Sheep were born and bred at home, uniquely identified and dates of birth were accurate to the season and year. Not all sheep in these flocks were sampled and tested for MVV-antibodies and the number of sheep selected in each flock was calculated to allow detecting at least one seropositive sheep with a $95 \%$ probability, assuming a flock seroprevalence of at least 5\% [32].

\subsection{Flock husbandry and housing}

Every farm was visited to complete a flock management questionnaire by personally interviewing the farmer and to measure sheep housing facilities. Table I describes flocks origin, number, size, breed and production system, weaning age of replacement lambs and sheep's housing time and space. 
Housing and management of replacement lambs was characteristic of the sheep production systems described above. They were naturally raised, except in three Latxa flocks where lambs stayed with their dams until 24-h-old and were then artificially raised with milk replacer until 6 weeks of age and one Assaf flock where lambs were raised artificially from birth with bottlefeeding of the dam's colostrum during the first day of life and milk replacer until 6-week-old. After being separated from their mothers, the replacement lambs in all flocks were raised as a separate flock until a few weeks before lambing at approximately 1 year of age. During this time, the lambs and adults used separate fields or field partitions and different buildings except one of the Latxa flocks that raised lambs artificially preweaning and two Assaf flocks that raised lambs with their dams preweaning, which used separate pens within the adult flock building when housing sheep.

The time sheep were indoors and the characteristics of the sheep buildings varied between and within systems and for adult and replacement sheep (Tab. I). Assaf adults were housed for longer periods, at somewhat greater stocking density and in more poorly ventilated buildings than adults in other systems. This was also the case for replacement lambs except that Latxa and Manchega cross-bred flocks housed lambs for longer than the adults, flooring space for lambs was slightly smaller in Latxa flocks compared to Assaf flocks and lamb sheds in Manchega cross-bred flocks were smaller than those for adults.

\subsection{Sampling and MVV-antibody testing}

All sheep $\geq 1$ year-old in intensive and semi-intensive flocks and 5065 sheep/flock aged/ $\geq 1$ year-old, in extensive flocks were blood sampled from the jugular vein with vacuum tubes with no anticoagulant. Sampling took place between November 2003 and April 2004 when replacement lambs were 12-14 months old and had not yet joined the adult flock. In the laboratory, serum was recovered and kept frozen at $-20^{\circ} \mathrm{C}$ until tested for MVVantibodies using an indirect commercial ELISA test (Elitest, Hyphen BIOMED, Neuville sur Oise, France). The assay has a sensitivity (se) and specificity (sp) and 95\% confidence intervals compared to the Agar Gel Imunodifussion Test (AGID) and western-blotting of $99.4 \%$ (98.4-99.8) and $99.3 \%$ (98.7-99.6), respectively [30].

Single tests were carried out in serum samples from Castile-León and Basque Country and samples were deemed positive for ELISA optical densities (OD) above or equal to the cut-off point and negative otherwise. The cut-off point was calculated according to the manufacturer's instructions using the following formula:

$$
\begin{aligned}
\text { Cut-off }= & \left(\mathrm{ODP}_{450-595}-\mathrm{ODN}_{450-595}\right) / 4 \\
& +\mathrm{ODN}_{450-595}
\end{aligned}
$$

where, OD $450-595$ : optical density at $450 \mathrm{~nm}$ using $595 \mathrm{~nm}$ as reference wavelength, of the positive control (P) and negative control $(\mathrm{N})$.

Moreover, to increase the precision of the estimated low seroprevalence in extensive Castile-La Mancha flocks, a major finding of this investigation, samples with OD values of 0.1 units below or above the cut-off value, more common in extensive than in intensive flocks (Tab. II), were tested once or twice again. The samples were tested once again only if the result of the second test was similarly above or below the cut-off point and accordingly, were classified as positive or negative. Instead, if the second test result was different from the first result a third assay was performed and the samples were considered positive if two of the three test results were above the cut-off OD values and inconclusive otherwise. Inconclusive results were not included in seroprevalence calculations. To 
Table II. Age-specific distribution of antibody-ELISA ROD values in seropositive sheep from 38 extensively raised cross-bred lamb-producing flocks, semi-intensively raised latxa dairy flocks and intensively raised Assaf flocks in Spain.

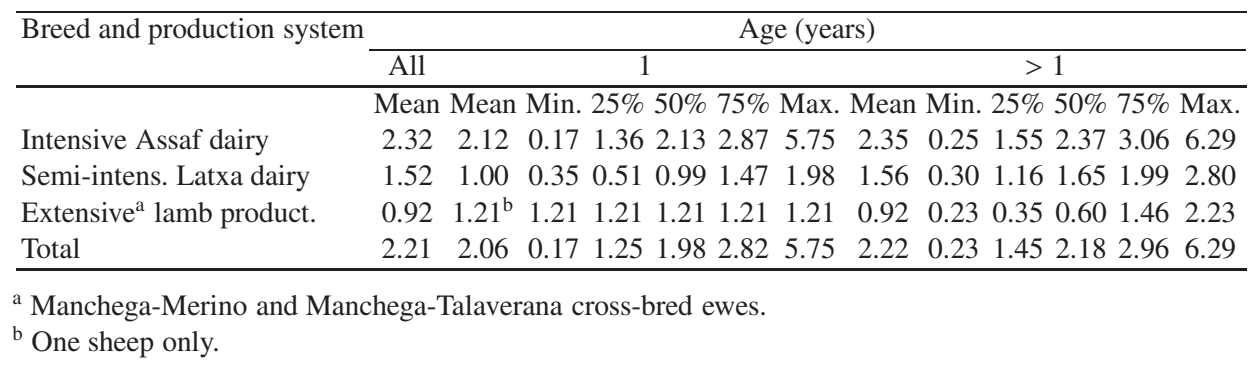

standardise the results, relative OD (ROD) were calculated by dividing the sample OD by the OD of the plate's positive control.

\subsection{Statistical analysis}

EpiInfo 2002 (CDC, Atlanta, USA) was used for all the statistical analysis, including sample size calculations, frequency distributions, chi-square tests with the Yate correction to compare proportions, non-parametric Kruskal-Wallis analysis to compare means and linear regression to investigate the relationship between ewe-flock seroprevalence and independent flock-average variables, including the number of days spent indoors per year and area of floor and open space and volume of housing per adult sheep available. All variables were incorporated in the models as continuous variables. The models were fitted using the least-square method. Partial F-tests were used to assess the significance of independent variables taken at the 5\% ( $p<0.05)$ level for a double-sided test.

\section{RESULTS}

\subsection{MVV-seroprevalence}

Seroprevalence was 77\% (3046/3974) in intensive Assaf dairy sheep, 25\% (391/1570) in semi-intensive Latxa dairy sheep and 5\% (72/1360) in extensive
Manchega cross-bred sheep ( $p<0.001$ ) Seroprevalence $(95 \% \mathrm{CI})$ in males and females was, respectively, $75 \%$ and $77 \%$ in intensive flocks ( $p>0.05), 19 \%$ and $25 \%$ in semi-intensive flocks $(p<0.05)$ and $8 \%$ (3-14) and 5\% (4-6) in extensive flocks $(p>0.05)$.

However, seroprevalence varied between flocks within sheep production systems. Table III presents the estimated seroprevalence in ewes and the distribution of ewe-flock seroprevalence in the three systems. Ewe seroprevalence was significantly higher in Assaf ewes than in the other ewes and in Latxa ewes compared to Manchega cross-bred ewes $(p<0.05)$. Among the latter, 6 flocks had $0 \%$ seroprevalence and the highest flock seroprevalence was $21 \%$, found in one flock (Tab. III). In contrast, seroprevalence in Assaf flocks was $44-96 \%$ and $>80 \%$ in half the flocks. Seroprevalence in Latxa flocks was intermediate between the other two breed groups and ranged between 5\% and $47 \%$ (Tab. III).

\subsection{Age-specific MVV-seroprevalence and relationship with mode of rearing of replacement sheep and adult flock seroprevalence}

Age-specific seroprevalence patterns in infected flocks differed between and within sheep production systems depending on 
Table III. Ewe and ewe-flock MVV-seroprevalence in 38 extensively raised cross-bred lambproducing flocks, semi-intensively raised Latxa dairy flocks and intensively raised Assaf flocks in Spain.

\begin{tabular}{|c|c|c|c|c|c|c|c|c|}
\hline \multirow{4}{*}{ Sheep breed and production system } & \multicolumn{3}{|c|}{ Ewes } & \multicolumn{5}{|c|}{ Flocks } \\
\hline & \multirow{3}{*}{ No. tested } & \multirow{3}{*}{$\%$ sero-positive } & \multirow{3}{*}{ No. tested } & \multicolumn{5}{|c|}{ \% seropositives } \\
\hline & & & & \multicolumn{4}{|c|}{ Quartiles } & \multirow{2}{*}{ - Max. } \\
\hline & & & & $101 m$ & $25 \%$ & $50 \%$ & $75 \%$ & \\
\hline Intensive Assaf dairy & 3913 & 77 & 10 & 44 & 66 & 82 & 94 & 96 \\
\hline Semi-intensive Latxa dairy & 1479 & 25 & 5 & 5 & 14 & 31 & 31 & 47 \\
\hline Extensive $^{\mathrm{a}}$ lamb production & 1262 & 5 & 23 & 0 & 0 & 4 & 7 & 21 \\
\hline
\end{tabular}

${ }^{a}$ Manchega cross Talaverana or Merino breeds.

the mode of rearing of replacement sheep during their first year of life and adult flock seroprevalence. This is graphically shown in Figure 1 where AF, AS, NF and NS refer to the mode of rearing of replacement lambs during the first year of life (A: artificially with milk replacer, $\mathrm{N}$ : naturally with the preweaning dam and F: in the adult flock building and $S$ : in a separate shed until 1-year-old). The rate of increase in seroprevalence with age was very slow in extensive flocks and one semi-intensive flock, moderate in the remaining semiintensive flocks and one intensive flock and high in the other intensive flocks.

In intensive Assaf flocks, seroprevalence among one-year-old sheep was the lowest $(20 \%)$ in the flock where lambs were raised artificially preweaning with ovine colostrum and milk replacer (AS) and $25-80 \%$ elsewhere according to adult seroprevalence and apparently independent of post-weaning place of rearing (Fig. 1). However, at 2 years of age, seroprevalence was $>60 \%$ in all flocks except one where seroprevalence was lower and only reached $60 \%$ among $\geq 4$-year-old sheep (Fig. 1). The age-specific pattern in most semi-intensive Latxa flocks was close to that in the latter intensive Assaf flock except that in the Assaf flock seroprevalence was greater among one year-old sheep and increased more slowly thereafter compared to two Latxa flocks that raised lambs arti- ficially preweaning (AS and AF) (Fig. 1). Like in Assaf flocks, there was little evidence in Latxa flocks of an association between place of rearing post-weaning and seroprevalence at one year of age.

\subsection{Relationship between adult flock-seroprevalence and housing variables}

The regression models confirmed the significant positive association between seroprevalence in the adult flock and the number of days sheep are housed per year $(p<0.001)$. However, these two variables were not associated within a particular sheep rearing system (results not shown). Moreover, adult flock seroprevalence was not associated with open area, flooring area or volume of shed available per sheep in models containing or excluding housing time. Figure 2 shows the observed unadjusted relationship between adult flock seroprevalence and housing time per year. The percentage of variation explained by the bivariate model was $86 \%\left(r^{2}=0.86\right)$ $(p<0.001)$ and did not change after including any of the other independent variables relating to stocking density and open area per sheep available.

\subsection{ELISA-antibody optical densities}

Mean ELISA-antibody OD values for seropositive and seronegative ewes were, 
(a) Intensive Assaf dairy flocks

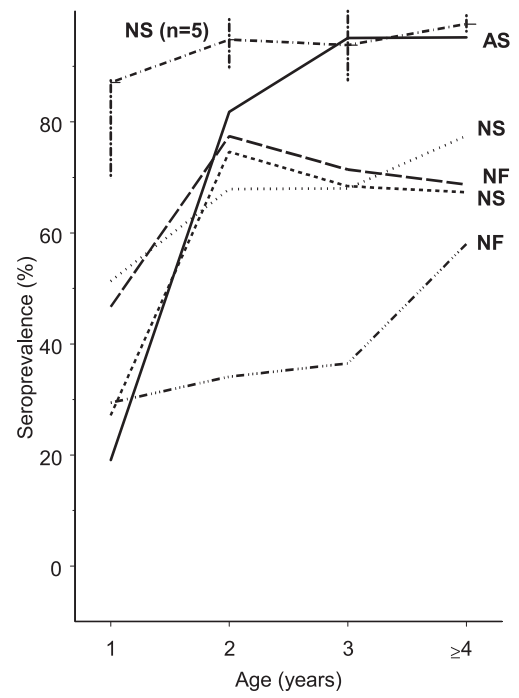

(b) Semi-intensive Latxa dairy flocks \& Extensive cross-bred flocks (bottom

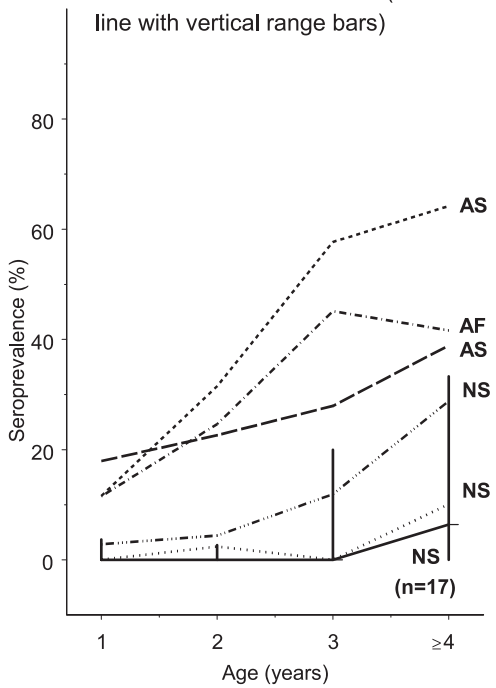

Figure 1. Age-specific MVV-seroprevalence in (a) intensive and (b) semi-intensive and extensive sheep flocks in Spain, including median and range for intensive $(n=5)$ and infected extensive $(n=17)$ flocks with very similar age-seroprevalence patterns. Symbols refer to replacement sheep's mode of rearing pre-weaning; $\mathrm{N}$ : naturally with the dam; A: artificially with bovine colostrum and milk replacer separate from the dam and place of rearing post-weaning until 1 year-old; F: in the adult flock building; S: in a separate shed with no other sheep.

1.66 and 0.025 in intensive Assaf flocks, 1.36 and 0.024 in semi-intensive Latxa flocks and 0.54 and 0.024 in extensive Manchega cross-bred flocks $(p<0.05)$, respectively. Moreover, one-year-old ewelambs had lower OD values than adult ewes $(p<0.05)$. Table II presents the age-specific distribution of ROD values in seropositive ewes in the different systems. Over $50 \%$ of one-year-old and $25 \%$ of older seropositive ewes in Assaf flocks had ROD values above the maximum ROD values of seropositive Latxa ewes. In contrast, ROD was $<1$ in more than $50 \%$ seropositive Manchega cross-bred ewes (Tab. II).

\section{DISCUSSION}

This is the first study comparing the MVV-seroprevalence in intensive semiintensive and extensive commercial sheep flocks in an MVV-endemic country and was carried out to provide some field evidence that horizontal transmission is the key route for MVV-infection and that lactogenic transmission alone may be insufficient to insure MVV-persistence in infected flocks, as suspected from previous experimental studies $[2,3,17]$. The results obtained strongly suggest that in sheep production systems where sheep do not have close contact, MVV-transmission is scarce and the opposite occurs when sheep are confined together most of the time. The latter is not a novel finding and has been amply reported [7], but the former has not been generally recognised and suggests that lactogenic transmission is relatively inefficient. The $\mathrm{R}_{\mathrm{e}}$ associated to lactogenic transmission could not be estimated since lambs raised with infected dams were exposed to both lactogenic and close direct 


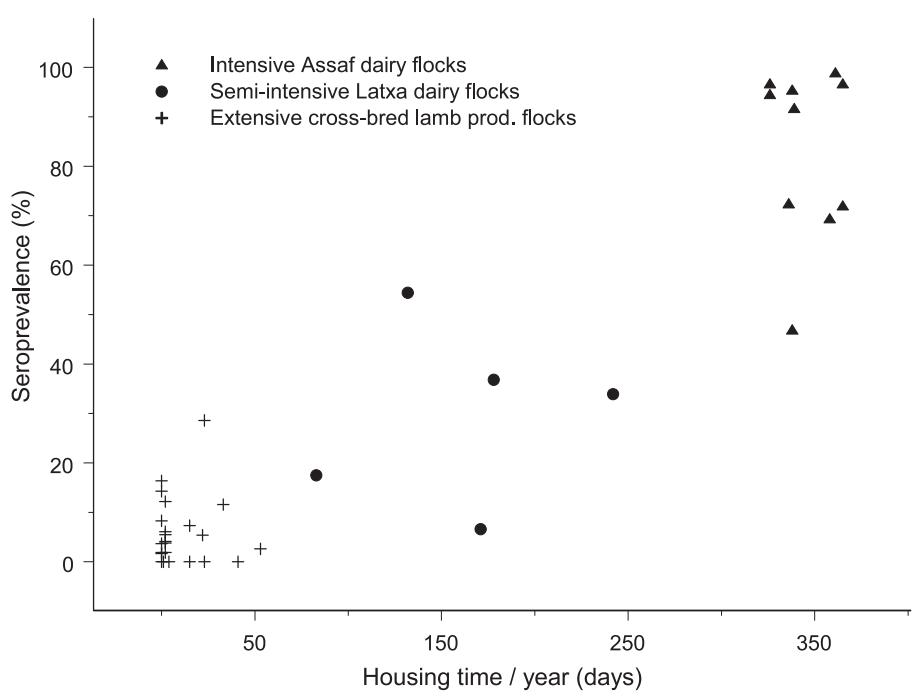

Figure 2. Relationship between flock seroprevalence and housing time in Spanish extensively raised cross-bred lamb-producing flocks, semi-intensively raised Latxa dairy flocks and intensively raised Assaf dairy flocks $(n=38)$.

horizontal infection except in one Assaf flock where lambs were raised under isolation with ovine colostrum and milk replacement. Interestingly, seroprevalence in one-year old sheep in this flock was $20 \%$, very similar to the experimentally estimated seroprevalence associated to naturally suckled colostrum from seropositive ewes [2]. However, the existence of several extensive flocks with $0 \%$ seroprevalence is compatible with $\mathrm{R}_{\mathrm{e}}$ associated to colostrum and milk being below or close to one. Consequently, MVV-control and eradication under such circumstances could be easy and inexpensive. The results in extensive flocks may help to explain the apparent absence of MVV in geographic areas such as Australasia, where most sheep are raised extensively. A further finding of this study was that antibody OD of seropositive sheep differed depending on flock seroprevalence and were greater in aged adults than in one year-old sheep. This could be related to greater virus challenge from possibly a larger variety of infectious strains to which hosts are exposed.
Given the limited number of flocks investigated and the criteria used to select flocks it could be argued that the observed seroprevalence is biased and not representative of these sheep production systems and that MVV-transmission between sheep readily occurred and sheep did or did not become infected as a result of for example, genetic breed-associated susceptibility and resistance to MVV-infection. Flock selection within intensive and extensive systems was not random and was limited to flocks under the care of two veterinary practitioners. As indicated before, the veterinarian responsible for the intensively raised flocks had expressed concern for MVV-infection and the contrary was the case for the veterinarian looking after the extensive flocks and this could be a source of strong selection bias. However, similarly high SRLV-seroprevalence is typical for example in intensive dairy goat herds in California [28] and in Icelandic sheep kept in close confinement in the winter [20] and similar low and null SRLV-seroprevalence was reported in 
extensive flocks in Patagonia [25,26]. Further bias might have been introduced by selecting the smaller flocks in the extensive system and those registered with the local milk-board among intensive flocks, but it is unlikely that either factor contributes greatly to explaining the enormous differences in MVV-seroprevalence in these two sheep production systems. Moreover, although certain alleles have been identified that confer goats and cows some degree of resistance to lentiviral infections [19, 29] and there are indications of inheritable susceptibility and resistance to MVVseroconversion in sheep [6], there is no evidence or previous suggestions, that major differences in flock MVV-seroprevalence are attributable to genetic differences between sheep. Breed-associated differences in susceptibility to infection have been proposed. However, differences are not consistent and no reports exist of particular breeds that always remain free or virtually free of MVV-infection after exposure to the virus. Resistance has also been linked to family lines within particular breeds, based on evidence that infection in flocks is often restricted to the progeny of infected ewes [14]. From these arguments it is reasonable to conclude that it is very unlikely that the observed seroprevalence in extensive and intensive flocks was strongly confounded by selection bias and breed differences. In contrast, the observed seroprevalence in semi-intensively raised Latxa dairy flocks $(<30 \%)$ is unlikely to be typical of this sheep production system because selected flocks had all implemented some form of MVV-control and can be considered low. Indeed, the estimated MVV-seroprevalence in the Basque Country was $55 \%$ in a large survey ${ }^{1}$ using

\footnotetext{
${ }^{1}$ Lorenzo González, El Maedi o neumonía progresiva en el conjunto de las enfermedades respiratorias crónicas del ganado ovino en la Comunidad autónoma Vasca, Doctoral thesis, Universidad de Zaragoza, Spain, 1989.
}

the AGID test, which is less sensitive than the ELISA used here.

The estimated seroprevalence in the Basque Country and the similarity in the age-specific seroprevalence patterns in some Assaf and Latxa flocks in the present study, suggest that the epidemiology of MVV-infection in these two production systems may not differ greatly. Moreover, seroprevalence differences between and within Assaf and Latxa flocks suggests that MVV-infection depends on additional factors, other than the degree of contact between infected and noninfected sheep. This is further supported by the finding that neither housing time nor any of the other housing variables investigated, explained differences in seroprevalence between intensive flocks. Other factors affecting MVV-infection may include the sheep's genetic susceptibility, the virulence of MVV-strains associated with a cytopathic effect $[15,16]$, the presence of other diseases such as ovine Pulmonary Adenomatosis that increase the risk of MVV-infection [11] and other unrecorded management and production practices. Specifically, the animal to animal dynamics of SRLV-horizontal infection is not well understood and little is known of certain husbandry aspects that affect the risk of MVV-infection. Although nose to nose contact between sheep is suspected to be a major risk factor for MVV-infection, all the intensive flocks in this study used feeding troughs that allowed direct nose to nose contact between sheep. Furthermore, the lack of an association between seroprevalence in one year-old sheep and place of rearing (flock building or separate shed), suggests that indirect contact transmission of SRLV may not be very efficient. This has been investigated, with discrepancies. For example, no CAEV-transmission between infected and non-infected does penned separately in the same building was found in a study [1], whereas in another, indirect CAEV- 
transmission between does in different pens in the same shed was reported and the risk of infection depended on the degree of separation between the animals [22]. Finally, little is known concerning the effect of production pressure on MVVinfection, however it has been considered an important risk factor [17] and the relationship between milk production and MVV-incidence of seroconversion in these flocks warrants further investigation.

Control wise, the results of this study are optimistic for some intensive Assaf flocks with moderate seroprevalence similar to some semi-intensively Latxa flocks where it was shown that seroprevalence could be gradually reduced by selectively culling seropositives [6] but it is unlikely that selective culling alone would permit elimination of infection in intensive flocks with high MVV-prevalence. Clearly more research is required to elucidate SRLVexcretion from infected animals and contact transmission between animals and the ways to avoid it in order to better control this lentiviral infection.

\section{ACKNOWLEDGEMENTS}

This work was financially supported by grants AGL2003-08977-c03-03 of the Ministerio de Ciencia y Tecnología and SED2003011 and SED2005008 of the Departamento de Agricultura of the Basque Government. We are also indebted for this to study flock owners for allowing us to work on their farms and to veterinarians Javier Otaola Otxoa, José Angel Fuertes Miguélez and Pedro José Mora Fernández for their invaluable help in selecting and sampling their client flocks.

\section{REFERENCES}

[1] Adams D.S., Klevjer-Anderson P., Carlson J.L., McGuire T.C., Gorham J.R., Transmission and control of caprine arthritis-encephalitis virus, Am. J. Vet. Res. 44 (1983) 1670-1675.
[2] Álvarez V., Arranz J., Daltabuit-Test M., Leginagoikoa I., Juste R.A., Amorena B., de Andrés D., Luján L.L., Badiola J.J., Berriatua E., Relative contribution of colostrum from Maedi-Visna virus (MVV) infected ewes to MVV-seroprevalence in lambs, Res. Vet. Sci. 78 (2005) 237-243.

[3] Álvarez V., Daltabuit-Test M., Arranz J., Leginagoikoa I., Juste R.A., Amorena B., de Andrés D., Luján L.L., Badiola J.J., Berriatua E., PCR detection of colostrumassociated Maedi-Visna virus (MVV) infection and relationship with ELISA-antibody status in lambs, Res. Vet. Sci. 80 (2006) 226234.

[4] Anderson R.M., May R.M., Infectious Diseases of Humans: dynamics and control, Oxford University Press, Oxford, United Kingdom, 1992.

[5] Benavides J., Gómez N., Gelmetti D., Ferreras M.C., García-Pariente C., Fuertes M., García-Marín J.F., Pérez V., Diagnosis of the nervous form of maedi-visna infection with a high frequency in sheep in Castilla y León, Spain, Vet. Rec.158 (2006) 230-235.

[6] Berriatua E., Ávarez V., Extramiana B., González L., Daltabuit M., Juste R., Transmission and control implications of seroconversion to Maedi-Visna virus in Basque dairy-sheep flocks, Prev. Vet. Med. 60 (2003) 265-279.

[7] Blacklaws B.A., Berriatua E., Torsteinsdottir S., Watt N.J., de Andres D., Klein D., Harkiss G.D., Transmission of small ruminant lentiviruses, Vet. Microbiol. 101 (2004) 199-208.

[8] Cutlip R.C., Lehmkuhl H.D., Brogden K.A., Sacks J.M., Breed susceptibility to ovine progressive pneumonia (Maedi-Visna) virus, Vet. Microbiol. 12 (1986) 283-288.

[9] Dawson M., Pathogenesis of maedi-visna, Vet. Rec. 120 (1987) 451-454.

[10] Esteban-Muñoz C., Tejon-Tejon D., Catálogo de razas autóctonas españolas, I. Especies ovina y caprina, Ministerio de Agricultura, Pesca y Alimentación, ISBN: 8474790905, 1986.

[11] González L., Juste R.A., Cuervo L.A., Idigoras I., Saez de Ocariz C., Pathological and epidemiological aspects of the coexistance of maedi-visna and sheep pulmonary adenomatosis, Res. Vet. Sci. 54 (1993) 140146.

[12] Greenwood P.L., North R.N., Kirkland P.D., Prevalence, spread and control of caprine 
arthritis-encephalitis virus in dairy goat herds in New South Wales, Aust. Vet. J. 72 (1995) 341-345.

[13] Houwers D.J., Visscher A.H., Defise P.R., Importance of ewe lamb relationship and breed in the epidemiology of maedi-visna virus infections, Res. Vet. Sci. 46(1989) 5-8.

[14] Houwers D.J., Economic importance, epidemiology and control, in: Petursson G., Hoff-Jorgensen R. (Eds.), Maedi-Visna and related diseases, Kluwer Academic Press, Massachussets, 1990, pp. 83-117.

[15] Lairmore M.D., Akita G.Y., Russell H.I., DeMartini J.C., Replication and cytopathic effects of ovine lentivirus strains in alveolar macrophages correlate with in vivo pathogenicity, J. Virol. 61 (1987) 40384042 .

[16] Lairmore M.D., Poulson J.M., Adducci T.A., DeMartini J.C., Lentivirus-induced lymphoproliferative disease. Comparative pathogenicity of phenotypically distinct ovine lentivirus strains, Am. J. Pathol. 130 (1988) 80-90.

[17] Leginagoikoa I., Daltabuit-Test M., Álvarez V., Arranz J., Juste R.A., Amorena B., de Andrés D., Lujan L.L., Badiola J.J., Berriatua E., Horizontal Maedi-Visna virus (MVV) infection in adult dairy-sheep raised under varying MVV-infection pressure investigated by ELISA and PCR, Res. Vet. Sci. 80 (2006) 235-241.

[18] MAPA, Encuestas ganaderas 2004, Subdirección general de estadísticas agroalimentarias, Ministerio de Agricultura, Pesca y Alimentación, 2004, pp. 24-25.

[19] Mirsky M.L., Olmstead C., Da Y., Lewinf H.A., Reduced bovine leukemia virus proviral load in genetically resistant cattle, Anim. Genet. 29 (1998) 245-252.

[20] Palsson P.A., Maedi and Visna in sheep, in: Kimberlin R.H. (Ed.), Slow virus diseases of animal and man, New York, American Elsevier, 1976, pp. 17-43.

[21] Pépin M., Vitu C., Russo P., Mornex J.F., Peterhans E., Maedi-visna virus infection in sheep: a review, Vet. Res. 29 (1998) 341367.

[22] Péretz G., Bugnard F., Calavas D., Study of a prevention programme for caprine arthritisencephalitis, Vet. Res. 25 (1994) 322-326.

[23] Perk K., Yaniv A., Gazit A., DeMartini J.C., Evaluation of vaccines for ovine lentivirus infection, AIDS Res. Hum. Retroviruses 12 (1996) 425-426.
[24] Peterhans E., Greenland T., Badiola J.J., Harkiss G., Bertoni G., Amorena B., Eliaszewicz M., Juste R.A., Krassnig R., Lafont J.P., Lenihan P., Petursson G., Pritchard G., Thorley J., Vitu C., Mornex J.F., Pépin M., Routes of transmission and consequences of small ruminant lentiviruses (SRLVs) infection and eradication schemes, Vet. Res. 35 (2004) 1-38.

[25] Robles C.A., Lanari M.-R., Pérez-Centeno M., Domingo E., Brucellosis and artritis encephalitis survey in cross-bred gotas from Neuquen province, Patagonia Argentina, Vet. Arg. 16 (1999) 1-6 (in Spanish).

[26] Robles C.A., Layana J.A., Cabrera R.F., Raffo F., Cutlip R., Retrospective serological study on Maedi (progressive pneumonia) in sheep and arthritis-encephalitis in goats from Patagonia, Argentina, Rev. Med. Vet. (Buenos Aires) 84 (2003) 96-99 (in Spanish)

[27] Rodríguez L., González M.A., Verberana J., García J.I., Vitoriano B., Condiciones socioeconómicas y perspectivas de futuro de los ganaderos de ovino de Castilla y León, in: El ganado ovino en Castilla y León: Estudio socio-económico y nuevas tecnologías de reproducción, Instituto Tecnológico Agrario, Junta de Castilla y León, 2005, pp. 27-52.

[28] Rowe J.D., East N.E., Thurmond M.C. Franti C.E., Pedersen N.C., Cohort study of natural transmission and two methods for control of caprine arthritis-encephalitis virus infection in goats on California dairy, Am. J. Vet. Res. 53 (1992) 2386-2395.

[29] Ruff G., Regli J.G., Lazary S., Occurrence of caprine leucocyte class I and II antigensa in Saanen goats affected by caprine arthritis (CAE), Eur. J. Immunogenet. 20 (1993) 285288.

[30] Saman E., Van Eynde G., Luján L., Extramiana A.B., Harkiss G., Tolari F., González L., Amorena B., Badiola J.J., A new sensitive serological assay for detection of lentivirus infections in small ruminants, Clin. Diagn. Lab. Immunol. 6 (1999) 734 740 .

[31] Snowder G.D., Gates N.L., Climp H.A., Gorham J.R., Prevalence and effect of subclinical ovine progressive pneumonia virus infection on ewe wool and lamb production, J. Am. Vet. Med. Assoc. 197 (1990) 475479.

[32] Thrusfield M., Veterinary Epidemiology, Blackwell Science, Oxford, United Kingdom, 1995, pp. 187-188. 